OFFICE

E

51

.1393

DIAN NOTES

no. 15

MONOGRAPHS

\title{
NMAIREF
}

IDITED By F. W. Hodge

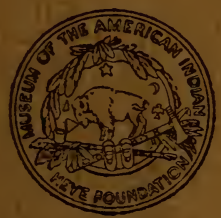

A SERIES OF PUBLICATIONS RELATING TO THE AMERICAN ABORIGINES

\section{SLATE MIRRORS OF THE TSIMSHIAN}

GEORGE T EMIMNS

\section{NEW YORK}

MUSEUM OF THE AMERICAN INDIAN HEYE FOUNDATION 
This series of Indian No'tes AND MonOGRaPhS is devoted primarily to the publication of the results of studies by members of the staff of the Museum of the American Indian, Heye Foundation, and is uniform with HisPanic Notes and Monographs, published by the Hispanic Society of America, with which organization this Museum is in cordial coöperation.

Only the first ten volumes of INDIAN NoteS AND MONOGRAPHS are numbered. The unnumbered parts may readily be determined by consulting the List of Publications issued as one of the series. 


$$
+
$$




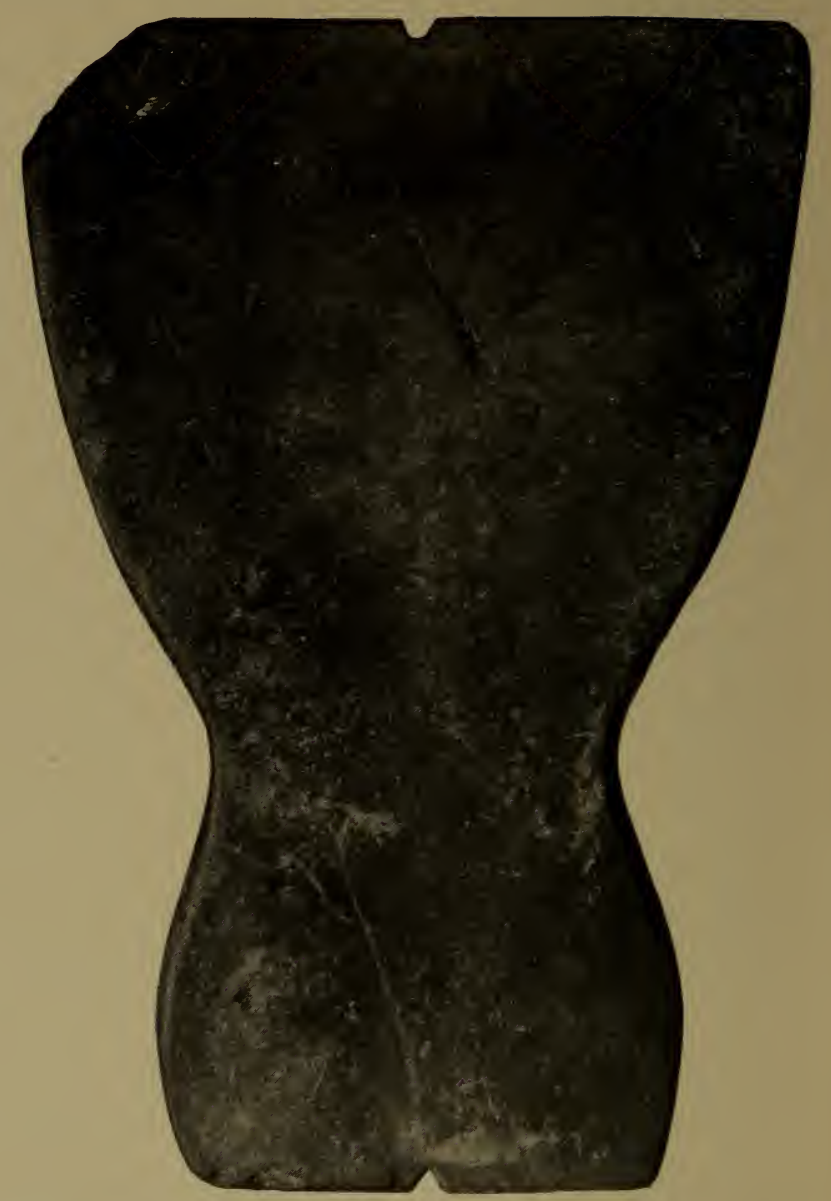

MIRROR OF HOMOGENEOUS GRAY-BLACK SLATE. LENGTH, $51 / 8 \mathrm{IN}$. Courtesy of the American Museum of Natural History 


\section{INDIAN NOTES \\ AND MONOGRAPHS}

Edited By F. W. Hodge

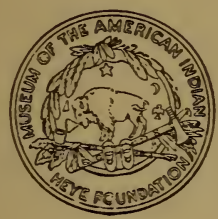

A SERIES OF PUBLICATIONS RELATING TO THE AMERICAN ABORIGINES

\section{SLATE MIRRORS OF THE TSIMSHIAN}

BY

GEORGE T. EMMONS

NEW YORK

MUSEUM OF THE AMERICAN INDIAN

HEYE FOUNDATION

1921 



\section{SLATE MIRRORS OF THE TSIMSHIAN}

BY

GEORGE T. EMMONS 



\begin{tabular}{|l|}
\hline \\
SLATE MIRRORS OF THE \\
TSIMSHIAN \\
By GeoRGE T. EMmons, \\
Lieutenant, U. S. Navy \\
$\begin{array}{l}\text { A of the Northwest coast of } \\
\text { America, its ragged shoreline } \\
\text { cut by deep fiords and in- }\end{array}$ \\
numerable bays, and flanked to seaward \\
by a continuous breakwater of islands, \\
offered protection and exceptional ad- \\
vantages to travel by canoe through \\
thousands of miles of navigable channels, \\
thus bringing together distant peoples. \\
This resulted in a general interchange of \\
ideas and products, and ultimately de- \\
veloped a distinct cultural area very \\
different from any other on the continent. \\
But notwithstanding this intimacy \\
through intermarriage and trade rela- \\
tions, each people retained its tribal \\
\hline I N D I A N N OT ES
\end{tabular}




\begin{tabular}{|c|c|}
\hline 6 & SLATE MIRRORS \\
\hline & $\begin{array}{l}\text { entity and excelled in certain arts and } \\
\text { industries. Such might be the result of } \\
\text { natural resources, as in the case of the } \\
\text { Haida war and traveling canoe fashioned } \\
\text { from the giant red cedar of the Queen } \\
\text { Charlotte islands, or of artistic sense and } \\
\text { skill, as shown by the same people in the } \\
\text { carved spoons, ladles, and dishes made } \\
\text { from the horn of the mountain goat and } \\
\text { sheep, which they procured in trade } \\
\text { with the mainland natives. Again, while } \\
\text { spruce is equally abundant throughout } \\
\text { the coast region, no other tribe ap- } \\
\text { proached the northern Tlingit in the } \\
\text { weaving and ornamentation of basketry } \\
\text { made from its roots. Furthermore, the } \\
\text { transfer of an industry is seen in the so- } \\
\text { called Chilkat blanket that originated } \\
\text { among the Tcimshian, but in the course } \\
\text { of time was lost to them and is perpetu- } \\
\text { ated by the Chilkat Tlingit, four hun- } \\
\text { dred miles distant. } \\
\text { But of particular interest are those arts } \\
\text { or products that never passed beyond } \\
\text { tribal limits, being confined to narrow } \\
\text { districts. Of this class the stone mirror }\end{array}$ \\
\hline & INDIAN NOTES \\
\hline
\end{tabular}




\section{TSIMSHIAN ORIGIN}

is a notable example: it was the product of the Tsimshian, and if known to their neighbors of the coast, the Tlingit, Haida, and Kwakiutl, it was never used by them, and is not represented in any of the very complete collections gathered among them, nor mentioned in the writings of any collector.

The Tsimshian as a whole are made up of several different people from both the interior and the coast, that have come together through intermarriage, migration, or accident, and in time have been welded together in a homogeneous body. They occupy the extreme northwest coast of British Columbia, the adjacent islands, and the valleys of the Skeena and the Nass. They comprise three dialectic divisions, made up of village bands, tribal as to territory, which is divided among the various clans, each of which is independent under its own chief. Hence there is no centralized governing power in either tribe or village.

Those known specifically as Tsimshian live directly on the seaboard and claim

\section{AND MONOGRAPHS}




\begin{tabular}{|c|c|}
\hline 8 & SLATE MIRRORS \\
\hline & $\begin{array}{l}\text { the lower waters of the Skeena as their } \\
\text { fishing rights. Their principal winter } \\
\text { habitation was at Metlakahtla until } \\
\text { I } 835 \text {, when the Hudson's Bay Company } \\
\text { established a post at Port Simpson, } \\
\text { where the majority of the people moved, } \\
\text { and it thus became the central trading } \\
\text { point on the northern coast, to which all } \\
\text { the different tribes flocked; this brought } \\
\text { prestigc and wealth to the residents, and } \\
\text { they became the most progressive and } \\
\text { important of the three divisions. } \\
\text { The Nishka people occupy the valley } \\
\text { of the Nass and form a link between the } \\
\text { coast and the interior. While possibly } \\
\text { less advanced than the Tsimshian of } \\
\text { the coast, they are equally intelligent, } \\
\text { and are artistic in a high degree. In } \\
\text { fact, I think that the most delicate and } \\
\text { pleasing examples of carving and painting } \\
\text { gathered throughout the whole extent of } \\
\text { the coast are from this people. } \\
\text { The Kitikshan ("people of the Shian } \\
\text { or Skeena"), who claim the Skeena river } \\
\text { as their own, are the original stock from } \\
\text { which the other two Tsimshian branches }\end{array}$ \\
\hline & INDIAN NOTES \\
\hline
\end{tabular}




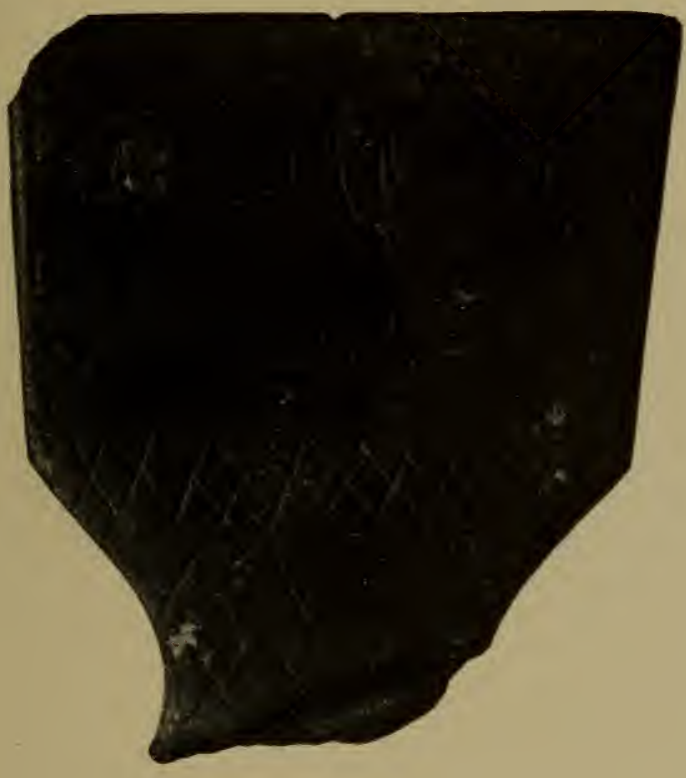

PART OF A CARVED MIRROR OF HOMOGENEOUS GRAY-BLACK SLATE. MAXIMUM WIDTH, $27 / 8$ IN.

Courtesy of the American Museum of Natural History 



\section{TRIBAL DIVISIONS}

came; they are scattered along the upper reaches of the river and its tributaries. The Kitikshan are the most primitive division of the three, and from their necessities and the character of their country are more hunters and trailers than water men, although they look to the river for their staple food-supply of salmon.

The stone mirror was common to all the divisions of the Tsimshian, and I found one specimen among their Athapascan neighbors, the Babine. Up to the present, after diligent search, only nine specimens have been located in either museums or private collections. None remain in possession of the people, although old houses and village-sites may yet yield a few. That so few of these objects survive a century of disuse is not surprising, when the fragile material and their delicate proportions are considered; for when the early European traders reached this coast, in the latter half of the eighteenth century, they distributed and traded unlimited numbers

\section{AND MONOGRAPHS}




\begin{tabular}{|c|c|}
\hline 10 & SLATE M I R RORS \\
\hline & $\begin{array}{l}\text { of small looking-glasses, which were so } \\
\text { much more practical and so inexpensive } \\
\text { that the native ones of stone were at } \\
\text { once discarded. } \\
\text { The Nishka claim to have been the } \\
\text { originators of the mirror in this region. } \\
\text { They fashioned it from a homogeneous, } \\
\text { grayish-black slate found in a ledge on } \\
\text { the north bank of the Nass, across from } \\
\text { the old village of Kitaix, flushing the } \\
\text { rock with water to procure pieces of } \\
\text { suitable size for working. It is a fact } \\
\text { that specimens found among the Nishka } \\
\text { and the coast Tsimshian seem to be of } \\
\text { like material and are similar in form, thus } \\
\text { tending to substantiate the Nishka } \\
\text { claim. The mirrors found on the upper } \\
\text { Skeena are of a much harder, blacker } \\
\text { stone, and somewhat different in shape, } \\
\text { while the one from the Babine of Bulkley } \\
\text { river is unlike any other in either material } \\
\text { or form. } \\
\text { The mirror was the property of the } \\
\text { women of the higher class, and was worn } \\
\text { suspended around the neck by a cord of } \\
\text { hide or of twisted root, hanging over the }\end{array}$ \\
\hline & INDIAN NOTES \\
\hline
\end{tabular}




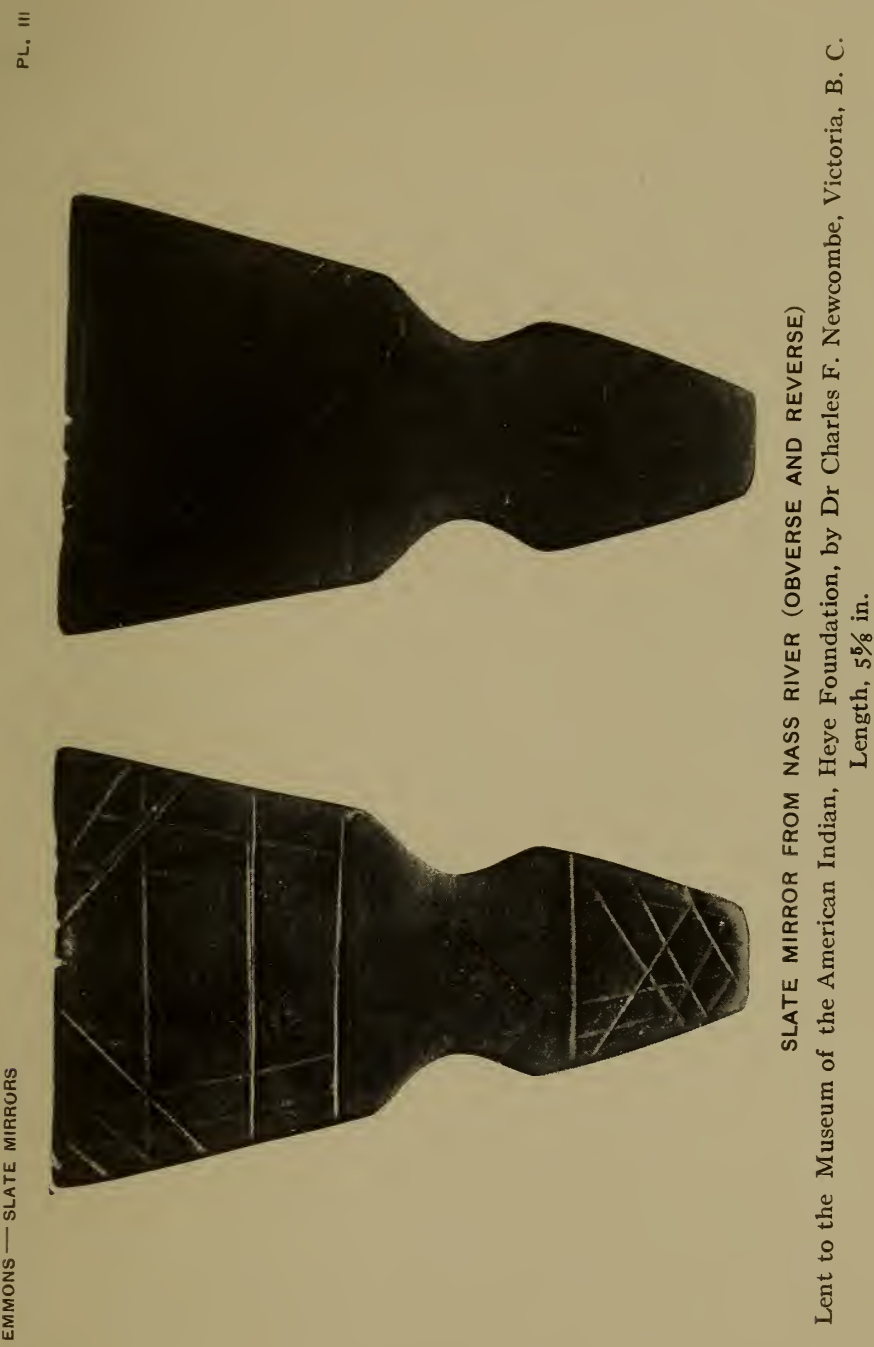





\section{N ISHKA C L A I M}

breast. When required for use, it was wetted (most conveniently licked or spit upon) and rubbed over, then held at such an angle to the light as was most favorable for reflection. If required for a comparatively long period, it was rubbed over with a thin coat of grease or oil. The usual form had a handle at the narrower end, a contracted neck curved or notched, around which the neck-cord passed, and an expanded reflecting surface. Some were double, that is, polished on both faces; others were incised or carved on one side, and notched along the upper or lower edges. Whether these marks were decorative in character or were designed for identification is not known, but certainly the work on the one illustrated in pl. II is ornamental in a high degree.

A comparison of all the known specimens shows the material to be of slate and exhibits general uniformity in shape, the most noticeable differences being in the handle and the connecting neck.

The five specimens (pl. I- $\mathrm{V}$ and

\section{AND MONOGRAPHS}




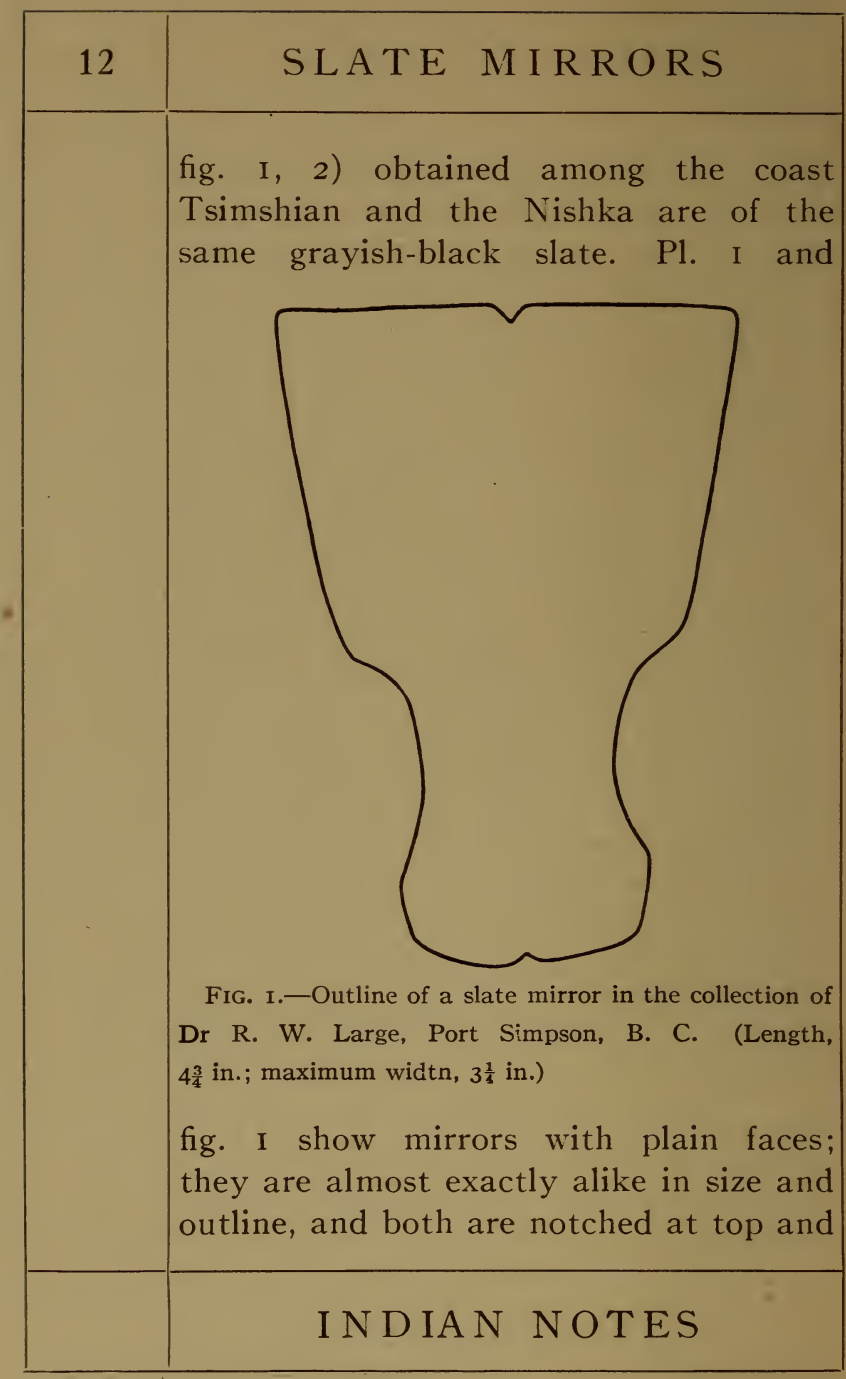




\begin{tabular}{l} 
F O R M A N D M A T E R I A L \\
bottom. Those illustrated in pl. III and \\
fig. 2 have straight sides, and the former \\
\hline Tistrict, in the collection of the Venerable Archdeacon \\
W. H. Collison, of Nass Harbor, B. C. (Length, 5 in.) \\
a longer handle; both are scored with \\
lines or cross-lines on the back.
\end{tabular}




\begin{tabular}{|l|l|}
\hline 14 & \multicolumn{1}{|c}{ S L A T E M I R R O R S } \\
\hline $\begin{array}{l}\text { which was procured, with the one shown } \\
\text { in pl. I, from a Tsimshian who knew only } \\
\text { that it had been found about the Nass, } \\
\text { is unfortunately broken, but it shows } \\
\text { the back of the reflecting surface clabor- } \\
\text { ately carved in low relief. The principal } \\
\text { design represents a crude face, more } \\
\text { human than animal, which, bisected, } \\
\text { exhibits two profiles difficult to determine. } \\
\text { Below are three parallel divisions of lines } \\
\text { and cross-lines. Ornamentation of pre- } \\
\text { cisely this character is commonly found } \\
\text { incised on the hunting and trapping } \\
\text { implements of bone employed by the } \\
\text { Tahltan and the Babine, with whom the } \\
\text { Nishka living farther inland come in } \\
\text { contact; it bears no resemblance to the } \\
\text { delicate technic of Nishka art of the last } \\
\text { hundred years, as known to us from their } \\
\text { artifacts of wood, bone, and ivory, but it } \\
\text { might express the work of a much earlier } \\
\text { period in the life of this people when some } \\
\text { of the divisions that claim an inland origin } \\
\text { still retained the practice of their ances- } \\
\text { tors and had not yet adopted the culture } \\
\text { of the coast tribes. }\end{array}$ \\
\hline I N D I A N N OT ES \\
\hline
\end{tabular}




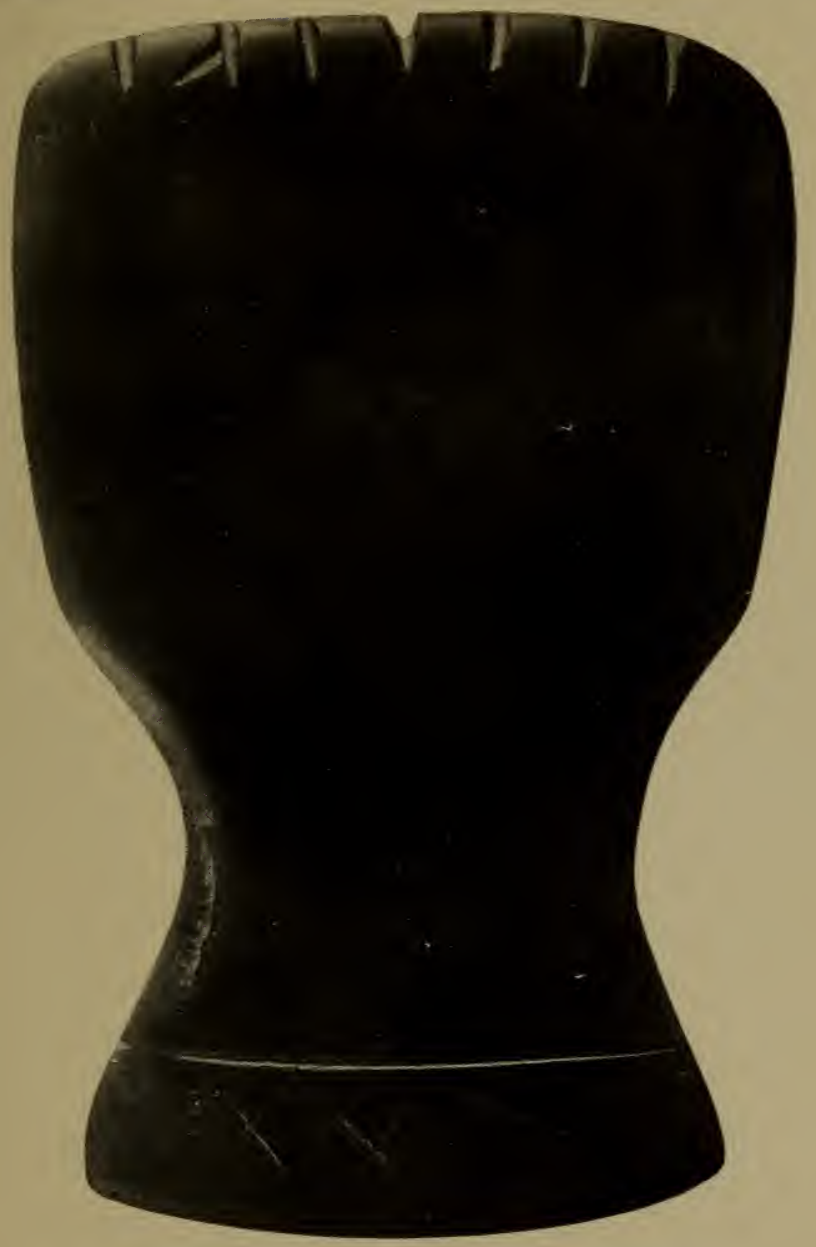

SLATE MIRROR FROM UPPER SKEENA RIVER

Courtesy of the Peabody Museum of Harvard University. Length, $71 / 8$ in. 



\section{FORM AND MATERIAL}

The two mirrors from the Kitikshan of the upper Skeena are of a hard, black slate, quite different from that of the Nishka specimens. Pl. IV exhibits one which, in size and shape, is similar to the mirrors of the Nishka, but the upper and lower edges are curved, a difference noticeable in all the specimens from the interior. It is polished on both faces, incised with cross-lines on one side of the handle, and notched along the upper edge.

Pl. V represents what is possibly the most interesting mirror of all, by reason of its symmetry and its peculiarly notched neck, together with the slight history associated with it. It was the property of an old shaman originally of the Kuldo band, but who, after this (the farthest inland of all the Skeena villages) had been abandoned, settled at Kispiox. He said that the mirror had been dug up on the old village-site and handed down through generations in his family. At that time nothing could induce him to part with it, and it was only in later

\section{AND MONOGRAPHS}




\begin{tabular}{|c|c|}
\hline 16 & SLATE M I R RORS \\
\hline & $\begin{array}{l}\text { FIG. 3.- Outline of a mirror of slate, without grain, } \\
\text { from the Babine village of Hawilget, at the mouth of } \\
\text { the Bulkley River cañon, B. C. Provincial Museum, } \\
\text { Victoria. (Length, 6 } 6 \frac{5}{8} \text { in.; width, } 4 \frac{1}{2} \text { in.; thickness, } \\
\frac{1}{2} \text { in.) }\end{array}$ \\
\hline & I NDIAN NOTES \\
\hline
\end{tabular}




\section{USE AMONG BABINE}

years, when it had descended to a younger generation, which thinks little of the past, that it was procured.

The mirror illustrated in fig. 3 was obtained from an older woman of the Babine living at Hawilget, on Bulkley river, near its mouth. There is no known history connected with it, except that it was an old family piece and had been preserved, as such things useless in themselves are treasured, for sentimental reasons by primitive peoples. It is quite different from any Tsimshian specimen, being of brownish slate, and larger and heavier, as it is at least half an inch in thickness. Both ends, moreover, are noticeably rounded, and the upper edge is scalloped. The handle and the reflecting surface are barely separated from each other by a very slight notch for the neck-cord.

For information respecting mirrors among the Déné, I wrote to Father A. G. Morice, whose intimate study of this people is so well known. $\mathrm{He}$ courteously replied at some length that

\section{A N D MONOGRAPHS}




\begin{tabular}{|c|c|}
\hline 18 & SLATE MIRRORS \\
\hline & $\begin{array}{l}\text { the stone mirror was unknown among } \\
\text { the Athapascan tribes of the far north and } \\
\text { that he had never seen a specimen among } \\
\text { them. Father Morice states: } \\
\text { "Further, the age of such articles, I mean } \\
\text { their antiquity, the time they came into use } \\
\text { among them, is usually predicated by the kind } \\
\text { of noun (primary or secondary root, common } \\
\text { substantive or verbal noun) by which they are } \\
\text { called. Now, the Carriers call a mirror pe-na'- } \\
\text { ts } \theta \text { nd } \theta-n \theta l ' e n \text {, which is merely a verb in the im- } \\
\text { personal to which is prefixed the preposition pe, } \\
\text { resulting in a verbal noun which means 'whereby } \\
\text { one looks at one's self.' This characterizes such } \\
\text { household and other implements as are adven- } \\
\text { titious among them." } \\
\text { The finding of a single specimen among } \\
\text { the Babine is not significant. Hawilget } \\
\text { was originally Kitikshan territory, and } \\
\text { was given to the Babine only after a } \\
\text { great rock-slide in the cañon of the } \\
\text { Bulkley had so obstructed the stream } \\
\text { that the salmon could not reach the } \\
\text { valley beyond, thus cutting off the } \\
\text { staple food of the former inhabitants. } \\
\text { In settling at this point, only four miles } \\
\text { from Hazelton, the Babine came in }\end{array}$ \\
\hline & I NDIAN NOTES \\
\hline
\end{tabular}




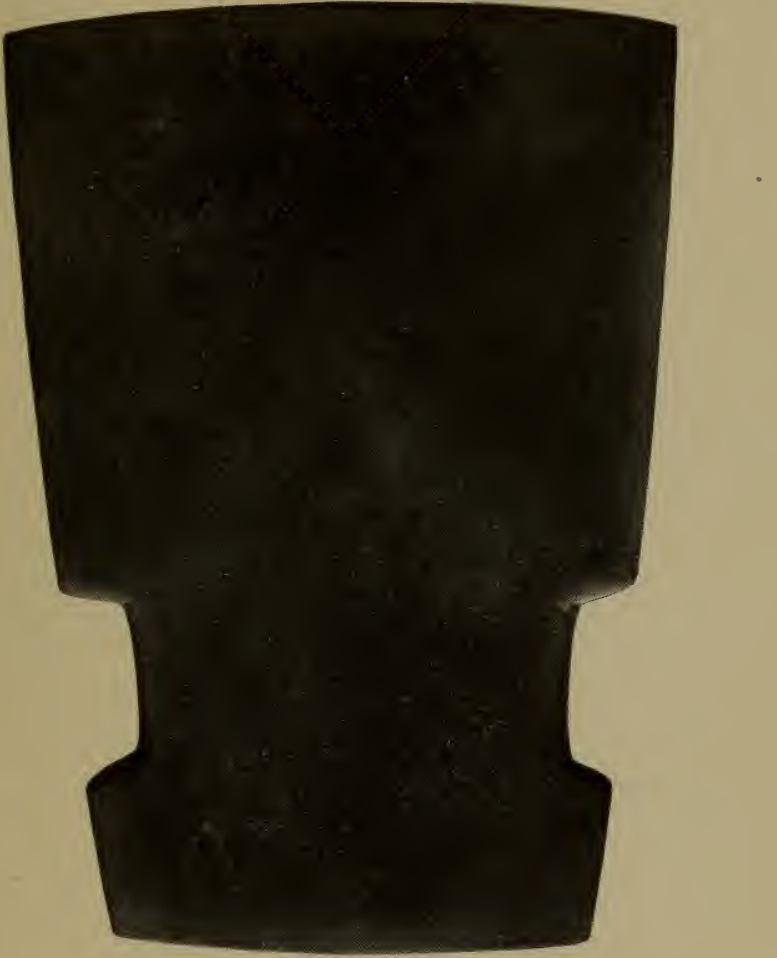

SLATE MIRROR DUG FROM THE DESERTED VILLAGE OF KULDO, UPPER SKEENA RIVER, B. C.

In the Museum of the American Indian, Heye Foundation. Length, $5 \frac{3}{4}$ in. 



\begin{tabular}{|l|l|}
\hline USE A M O N G S A L I S H & 19 \\
\hline constant intercourse with the Kitikshan, \\
and being a crude people, copied much \\
from their neighbors. This might readily \\
account for this piece being in their \\
possession-made by them or possibly \\
dug up in gardening, as this locality has \\
furnished some of the most remarkable \\
and beautifully carved stone clubs that \\
have been found in the Northwest. \\
Mr J. A. Teit, of Spences Bridge, \\
British Columbia, writes me as follows in \\
answer to an inquiry regarding this \\
article among the Salish: \\
"The only direct information I have is from \\
the Thompson [Indians], who claim that long \\
ago, stone, generally of a very dark color, was \\
occasionally made into or used as looking- \\
glasses by them; they say the stone was rare \\
and seldom to be found. It took a very high \\
polish, and fragments used for looking-glasses \\
were generally small about 4 inches in width or \\
height) and thin. Some of them were bored for \\
suspension. I have never seen any myself. \\
The Thompson and other interior Salish tribes \\
also used looking-glasses made of mica, which \\
mineral can be found in large clear sheets in \\
some places. It seems these were comparatively \\
common, whilst stone ones were very rare. \\
$\begin{array}{l}\text { an } \\
\text { A D M ON O G R A P HS }\end{array}$ \\
\hline
\end{tabular}




\begin{tabular}{|c|c|}
\hline 20 & SLATE MIRRORS \\
\hline & $\begin{array}{l}\text { The remaining living old men here (Spences } \\
\text { Bridge) can give me no further light on the stone } \\
\text { mirrors, except to say they were oblong in shape, } \\
\text { thin, and about four inches in length; some were } \\
\text { perforated or notched at one end like some } \\
\text { sap-scrapers. They were very rare and none } \\
\text { of the three men I lately interviewed remem- } \\
\text { bered having seen any. Those they had heard } \\
\text { of belonged to old men of Lytton or the neigh- } \\
\text { boring part of Fraser river above." } \\
\text { From these general notes, particularly } \\
\text { from mention of the shape of the sap- } \\
\text { scraper, the material, and the size, the } \\
\text { suggestion arises whether this article } \\
\text { might not have originated hereabouts } \\
\text { and have been carried to the coast } \\
\text { through emigration or have been brought } \\
\text { thither in trade by the more northerly } \\
\text { interior tribes. } \\
\text { The stone mirror is variously named } \\
\text { among the Tsimshian and neighboring } \\
\text { people, as noted below: } \\
\text { Tsimshian: nicks-klu-nesk gum tzel, 'reflection } \\
\text { of face, also dza gdt, 'shaped like a } \\
\text { Nishka: na haun, indicating the shining skin } \\
\text { of a fresh salmon, from na, a prefix } \\
\text { indicating the properties of; haun, }\end{array}$ \\
\hline & I NDIAN NOTES \\
\hline
\end{tabular}




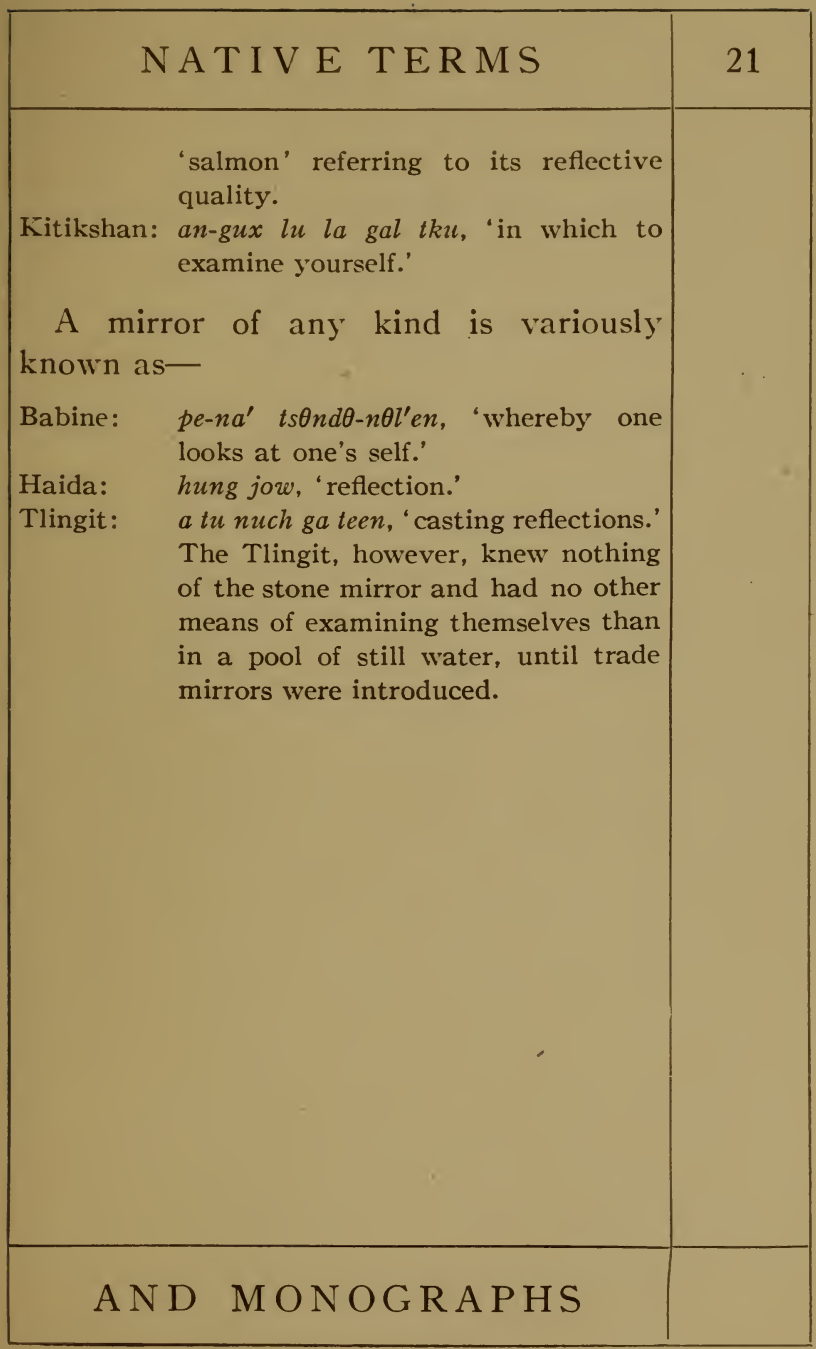






SMITHSONIAN INSTITUTION LIBRARIES

||||||||||| |||||||||||||||||||| |||||||||||||| ||||||||||||||| |||||||||||||||||

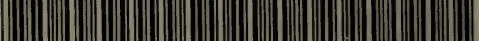

|||||||||||||||||||||||||||||||||||||||||||| ||||||||||||||| |||||||||| ||||||||

39088015621626 